\title{
ОПТИМІЗАЦІЯ ЛІКУВАННЯ ЖІНОК 3 ХРОНІЧНИМ ЕНДОМЕТРИТОМ ЯК РЕЗЕРВ ПІДВИЩЕННЯ ФЕРТИЛЬНОСТІ
}

\author{
Донська Ю. В., к. мед. н. \\ Лоскутова Т. О., д. мед. н. \\ Сімонова Н. В., к. мед. н. \\ Петулько А. П., к. мед. н. \\ Державний заклад «Дніпропетровська медична академія МОЗ України» \\ Кафедра акушерства і гінекології
}

DOI: https://doi.org/ 10.31435/rsglobal_ws/31102018/6175

\section{ARTICLE INFO}

Received: 09 August 2018

Accepted: 18 October 2018

Published: 31 October 2018

\section{KEYWORDS}

chronic endometritis, diagnostics,

infertility,

therapy,

dydrogesterone.

\begin{abstract}
The worsening demographic situation encourages the search for new reserves to improve reproductive potential. The maximum incidence of chronic endometritis $(97.6 \%)$ is $26-35$ years old - the most important in the implementation of reproductive function. The lack of a single concept for the pathogenesis of HE, the purge of clinical manifestations impedes the creation of well-grounded therapy in women of childbearing age. The aim of the study was to increase the effectiveness of treatment of patients with confirmed chronic endometritis in order to restore fertility. It is proved that the use of the scheme, which includes antibacterial (doxycycline $100 \mathrm{mg}$ orally 2 times a day and metronidazole $500 \mathrm{mg} 2$ times a day for 14 days in one menstrual cycle) and cyclic progestogen (didrogesterone at a dose of $20 \mathrm{mg}$ per day with 15 to 25 days of the menstrual cycle - within three months), therapy can restore the morpho-functional endometrium potential by $88 \%$ compared with the initial rates.
\end{abstract}

Citation: Донська Ю. В., Лоскутова Т. О., Сімонова Н. В., Петулько А. П. (2018) Optymizatsiia Likuvannia Zhinok z Khronichnym Endometrytom yak Rezerv Pidvyshchennia Fertylnosti. World Science. 10(38), Vol.1. doi: 10.31435/rsglobal_ws/31102018/6175

Copyright: () 2018 Донська Ю. В., Лоскутова Т. О., Сімонова Н. В., Петулько А. П. This is an open-access article distributed under the terms of the Creative Commons Attribution License (CC BY). The use, distribution or reproduction in other forums is permitted, provided the original author(s) or licensor are credited and that the original publication in this journal is cited, in accordance with accepted academic practice. No use, distribution or reproduction is permitted which does not comply with these terms.

Актуальність. Хронічний ендометрит (XЕ) є однією з важливих причин безпліддя, невдалих спроб екстракорпорального запліднення та невиношування вагітності $[1,2]$. Хронічний ендометрит це клініко-морфологічний синдром, при якому в результаті персистуючого пошкодження ендометрія інфекційним агентом виникають множинні вторинні морфофункціональні зміни, що порушують циклічну біотрансформацію і рецептивність слизової оболонки тіла матки. Доведено, що в запальний процес при хронічному ендометриті залучається не тільки функціональний, але й базальний (камбіальний) шар, часто уражається і міометрій $[1,2]$. Максимальна частота XE $(97,6 \%)$ припадає на вік 26-35 років - найбільш важливий в реалізації репродуктивної функції. Встановлено, что при безплідді (максимально при трубно-перитонеальному) частота ХЕ ставити 12-68\%, при невдалих спробах ЕКЗ - 60-80\%, при мимовільних абортах - 90-92\% Г2]. Незважаючі на численні наукові дослідження и відомості про значну пошіреність ХЕ (60-65\%) відсутні стандартизовані клінічні рекомендації і протоколи з лікування хронічного ендометриту.

Значно ускладнюють ситуацію труднощі в розпізнаванням ХЕ. Хронічний ендометрит характеризується малосимптомністю і стертістю клінічних проявів. Часто єдиним клінічним проявом 
$\mathrm{XE} \epsilon$ безпліддя або невиношування вагітності [3-6]. Найбільш частою причиною XE $є$ інвазивні втручання в порожнині матки, інфекційно-запальні ускладнення після пологів, використання ВМС, інфекції піхви і шийки матки, деформація порожнини матки з порушенням циклічного відторгнення ендометрія, невдале спорожнення матки без гістероскопічної візуалізації і подальшої повноцінної реабілітації травмованого ендометрію [7]. Відсутність єдиної концепції патогенезу ХЕ, яка визначає механізми формування і взаємозв'язку різних патологічних процесів в ендометрії, механізмів порушення макро- і мікроскопічних функцій, особливостей структури і функції слизової матки, перешкоджає створенню обгрунтованої терапії у жінок фертильного віку.

Слабкою ланкою у вивченні хронічного ендометриту визнана мікробіологічна діагностика: відсутність мікробного агента в ендометріальних зразках або, навпаки, персистенція умовнопатогенної флори зачіпають невирішене понині питання інфекційного тригера. Наявність можливого взаємозв'язку ХЕ з гіперпроліферативними процесами ендометрія, залишає відкритим питання про кореляцію механізмів регуляції програмованої клітинної загибелі в ендометрії з різним рецепторним статусом і морфо-структурними особливостями $[8,9]$.

Очевидно, що для ендометрія, як і для багатьох інших тканин організму, характерний добовий циркадний ритм активності генів Г10]. Десинхронізація оваріального i ендометріального циклу може призводити до втрати рецептивності ендометрія без видимих причин. На тлі XE спостерігається ослаблення експресії естрогенових і особливо прогестеронових рецепторів в епітеліальних і стромальних клітинах. Це знижує їх чутливість до стероїдів, тому відзначається неповноцінність циклічних перетворень при задовільному синтезі естрогенів і прогестерону. Структурні зміни в ендометрії супроводжуються порушенням його функції, зокрема продукції ендометріальних білків, які відображають повноцінність секреторних перетворень ендометрія в лютеїнову фазу циклу. Найпростішим і доступним, на перший погляд, здавався метод гормональної терапії, заснований на відомій фізіологічній залежності росту і функції ендометрія від рівня оваріальних стероїдів. Однак терапія хронічного ендометриту вимагає іншого підходу. Тут вкрай важливо дотримуватися принципу «проліферація без запалення». Так, застосування естрогенів не принесло очікуваних результатів [10]. Ендогенні і екзогенні естрогени посилюють процеси проліферації, одночасно активуючи запальну реакцію, що перешкоджає лікуванню хронічного ендометриту, але необхідне для здійснення імплантації. У зв'язку з цим слід проводити підготовку ендометрію до вагітності поетапно, з виключенням ймовірних причин недостатнього росту і відновлення рецептивності, включаючи в себе антибіотикотерапію хронічного ендометриту, а також застосування прогестагенів, потенційно здатних відновити рецептивність ендометрію [10]. Цікаві дані, що свідчать про відновлення рецептивності, були отримані Адольфом Е. Шиндлером [10] в результаті дослідження морфофункціонального стану ендометрію у жінок із застосуванням дідрогестерону, який відрізняється від інших прогестагенів здатністю зв'язуватися виключно з прогестероновими рецепторами (табл. 1).

Таблиця 1. Зв'язування прогестагенів зі стероїдними рецепторами

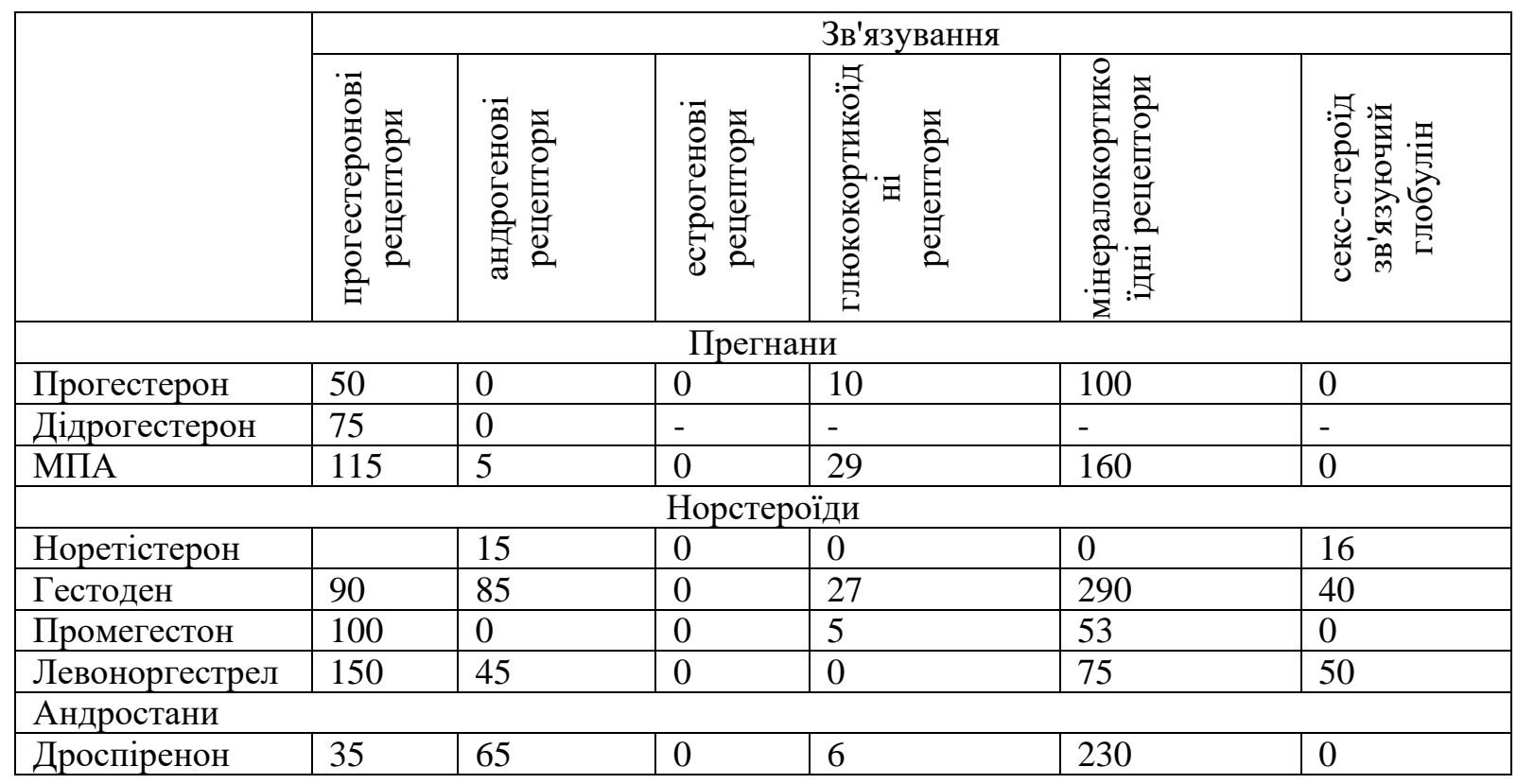


Проведені дослідження показали, що дідрогестерон викликає повну секреторну трансформацію ендометрія, включаючи дозрівання залозистого і стромального елементів. До того ж, дідрогестерон не має естрогенної, андрогенної або адренокортикоідної активності, не може метаболізуватися в естрогени, крім того, має антиестрогенну активність в ендометрії.

Другий етап лікування хронічного ендометриту скерований на відновлення морфофункціонального потенціалу ендометрію: корекцію метаболічних порушень та наслідків ішемії, відновлення гемодинаміки й активності рецепторного апарату ендометрія.

Неоднозначність кореляції клінічних, ехографічних i гістологічних характеристик довершує ймовірність діагностичних похибок, тому увага фахівців має бути зосереджена на гістопатичних особливостях кожного 3 варіантів XE Г11]. Розробка комплексної системи діагностики і лікування зазначеної нозології, акцентуація значущості предгравидарного етапу $є$ важливим вектором вирішення проблеми збереження репродуктивного потенціалу у жінок 3 ХЕ.

Метою дослідження було підвищення ефективності лікування пацієнток 3 підтвердженим хронічним ендометритом задля відновлення фертильності.

Матеріали і методи. У клінічному дослідженні брали участь 117 жінок репродуктивного віку з безпліддям або звичним невиношуванням. Умовами для відбору були наявність діагностованої при ультразвуковому дослідженні (УЗД) органів малого тазу на 22 - 24 день менструального циклу (МЦ) гіпоплазії ендометрію (товщина менше 8 мм); наявність морфологічного висновку зразків ендометрію 3 підтвердженими діагностичними критеріями хронічного ендометриту; результати обстеження на захворювання, що передаються статевим шляхом методом полімеразної ланцюгової реакції та бактеріологічне дослідження посіву 3 цервікального каналу й порожнини матки 3 відсутністю ідентифікації специфічного інфекційного агента.

Проводилось загальноклінічне обстеження, гінекологічне обстеження, посів 3 цервікального каналу та порожнини матки, УЗД стану ендометрію на 22 - 24 день менструального циклу. «Золотим стандартом» діагностики хронічного ендометрита $\epsilon$ морфологічне дослідження ендометрія, яке повинно бути обов'язковою ланкою в алгоритмі обстеження. Взяття матеріалу для гістологічного дослідження проводилось у другу фазу циклу за допомогою гістероскопії з прицільною біопсією. Гістероскопічні критерії ХЕ були наступні: мікрополіпи, набряк строми, діфузна гіперемія. Проведення гістероскопії в обстежуваних пацієнток було важливим також для виключення внутрішньоматкової патології.

Критеріями морфологічної діагностики хронічного ендометриту були наступні: запальні інфільтрати, які складаються переважно з лімфоїдних елементів, розташованих навколо залоз та кровоносних судин, вогнищеві інфільтрати у вигляді «лімфоїдних фолікулів» які розташовуються не тільки в базальному, але й у всіх відділах функціонального шару, наявність плазматичних клітин, вогнищевий фіброз строми, склеротичні зміни стінок спіральних артерій ендометрія.

Після обробки результатів дослідження, для подальшого лікування пацієнтки були розподілені на дві групи. Основну групу склали 59 жінок, які отримували антибактеріальну терапію: доксициклин по 100 мг перорально 2 рази на добу і метронідазол по 500 мг 2 рази на добу протягом 14 днів, а також дідрогестерон у дозі 20 мг на добу 315 по 25 день менструального циклу протягом трьох місяців. Дідрогестерон сприяє відновленню ендометрія у жінок, переходу слизової оболонки матки 3 проліферетивної фази в секреторну, при заплідненні створює необхідні умови для розвитку заплідненої яйцеклітини. Окрім впливу на репродуктивну систему жінки дідрогестерон має властивість створювати системні ефекти: регуляція глюкози в плазмі крові, підвищення температури тіла, стимуляція дихальної активності та підвищення рівня амінокислот в плазмі крові. Групу порівняння склали 58 жінок, що отримували подібну антибактеріальну терапію протягом 14 днів.

Ефективність лікувальної тактики оцінювали на підставі скарг, змін гінекологічного статусу, результатів УЗД органів малого тазу на 22 - 24 день менструального циклу та пайпельбіопсії ендометрія на 25-27-й день МЦ на третьому місяці лікування.

Статистичну обробку результатів дослідження проводили з використанням ліцензійних комп’ютерних програм Microsoft Excel 2010 і Graph Pad Prism 5 (номер ліцензії 35B73650-689911DA-6784-00232A9018BE). Основні характеристики представлені у вигляді кількості спостережень (n), середньої арифметичної величини (M), стандартної помилки середньої $( \pm \mathrm{m})$, відносних величин (абс., \%), рівня статистичної значущості (р). Нормальність розподілу кількісних ознак оцінювали за допомогою критеріїв Шапіро-Уілка та Колмогорова-Смірнова. Порівняння статистичних характеристик у групах проводилось iз використанням параметричних і непараметричних критеріїв: оцінка вірогідності відмінностей середніх для незв'язаних вибірок - за критеріями Стьюдента (t), вірогідність відмінностей якісних 
показників - за критерієм Хі-квадрат Пірсона $\left(\chi^{2}\right)$, в тому числі 3 поправкою Йєтса (Yates corrected), точним критерієм Фішера. Розбіжність вважали достовірною за умови р <0,05.

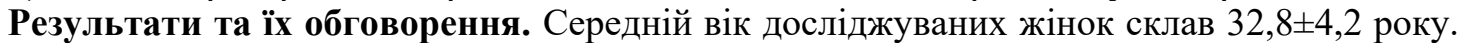
Клінічні групи, що досліджувались, не відрізнялися вірогідно між собою за віком, індексом маси тіла та тривалістю спостереження ( $>0,05)$. Отже, усі відмінності поміж групами були за рахунок медикаментозного лікування.

При ультразвуковому дослідженні органів малого тазу перед початком лікування діагностувалася гіпоплазія ендометрія 3 товщиною від 3,2 до 5,3 мм; зміна структури ендометрія, виникнення в зоні серединного М-еха ділянок підвищеної ехогенності різної величини і форми, всередині цих ділянок виявлялися зони неправильної форми зі зниженою ехогенністю.

Під час проведення гістероскопії найбільш частими ознаками запального процесу в ендометрії були: нерівномірна товщина ендометрія (86,4\% жінок основної групи, 84,4\% групи порівняння), нерівномірне забарвлення слизової оболонки (44,1\% і 62,0\% відповідно), гіперемія слизової оболонки (77,9\% і 82,7\% відповідно), точечні крововиливи (52,5\% і 44,8\% відповідно).

У жінок основної групи встановлено збільшення товщини ендометрія в порівнянні 3 початковими показниками. Так, у 47 пацієнток (79,6 \%) товщина ендометрію склала 10,5 2,3 мм, ехоструктура ендометрія - однорідна, відповідає лютеїновій фазі менструального циклу. При гістологічному дослідженні біоптату 3 порожнини матки, проведеному за допомогою пайпель - біопсії на 25-27-й день менструального циклу, у 52 обстежуваних (88 \%) структура ендометрія відповідала секреторній фазі менструального циклу.

У жінок групи порівняння після 3-х місяців лікування при проведенні УЗ - контролю стану ендометрія на 22-24 день менструального циклу у 51 (87,9\%) пацієнтки зберігалася

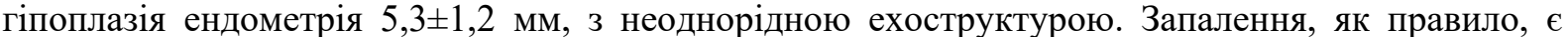
дифузним процесом, однак окремі ділянки можуть мати неоднакову реакцію, що призводить до локальних змін. При ультразвуковому дослідженні відзначалась різна товщина слизової оболонки передньої і задньої стінок матки. Лише у 7 досліджуваних (12\%) товщина ендометрія склала 9,8土2,4 мм, з однорідною ехоструктурою, без локальних змін $(\mathrm{p}<0,05)$. При проведеній пайпель - біопсії зразків ендометрія (25-27-й день менструального циклу) в 54 випадках були визначені осередкові фіброзні зміни строми ендометрія і тільки 4 пацієнтки (6,9\%) мали морфологічно ендометрій без патологічних змін $(\mathrm{p}<0,05)$.

Комбіноване поетапне лікування хронічного ендометриту призводить до морфофункціонального відновлення ендометрія, що забезпечує сприятливі умови для імплантації і розвитку плідного яйця.

\section{Висновки.}

1.В ході проведеного дослідження було встановлено, що двоетапне лікування атрофічного варіанту хронічного ендометриту $є$ ефективним методом реабілітації слизової оболонки матки та іі підготовки до вагітності.

2. Доведено, що використання схеми, до складу якої входить антибактеріальна (доксициклин по 100 мг перорально 2 рази на добу і метронідазол по 500 мг 2 рази на добу протягом 14 днів протягом одного менструального циклу) і циклічна гестагенна (дідрогестерон у дозі 20 мг на добу з 15 по 25 день менструального циклу - протягом трьох місяців) терапія дозволяє відновити морфо-функціональний потенціал ендометрія на 88 \% в порівнянні 3 початковими показниками.

\section{ЛIТЕРАТУРА}

1. Лызикова, Ю. А., (2015). Хронический эндометрит как причина нарушении репродуктивной функции у женщин. Проблемь здоровья и экологии, 3(45), 9-16.

2. Johnston-MacAnanny, E., Hartnett, J., Engmann, L., Nulsen, J., Sanders, M. and Benadiva, C. (2010). Chronic endometritis is a frequent finding in women with recurrent implantation failure after in vitro fertilization. Fertility and Sterility, 93(2), pp.437-441.

3. Широкова, Д. В., Калинина, Е. А., Полина, М. Л., Петров, Ю. А. , (2015). Морфофункциональная вариабельность эндометрия как основа дифференцированного лечения бесплодия. Современные проблемы науки и образования. 6. http://www.science-education.ru/ru/article/view?id=23764

4. Таболова, В. К., Корнеева, И. Е. (2013). Влияние хронического эндометрита на исходы программ вспомогательных репродуктивных технологий: морфофункциональные и молекулярно-генетические особенности. Акушерство и гинекология, 10, 17-22.

5. Cicinelli E., Ballini A., Marinaccio M., Poliseno A., Coscia M.F., Monno R., De Vito D. (2012). Microbiological findings in endometrial specimen: our experience. Arch. Gynecol. Obstet, 285(5), 1325-9. 
6. Авраменко, Н. В., Грідіна, І. Б., Ломейко, О. О. (2015) Хронічний ендометрит як чинник порушення репродуктивного здоров'я жінок. Запорізький медичний журнал, 6 (93), 93-97.

7. Потапов, В. О., Медведєв, М. В., Донська, Ю.В. (2013). Проблема поєднаних гіперпроліферативних процесів матки (огляд літератури). Актуальні питання педіатрї, акушерства та гінекологї, 11(1), $138-141$.

8. Manukhin, I., Sementsova, N., Mitrofanova, Y. and Livshits, L. (2018). Chronic endometritis and habitual miscarriage. Medical Council, (7), 46-49.

9. Cicinelli, E., Matteo, M., Tinelli, R., Pinto, V., Marinaccio, M., Indraccolo, U., ... Resta, L. (2014). Chronic Endometritis Due to Common Bacteria Is Prevalent in Women with Recurrent Miscarriage as Confirmed by Improved Pregnancy Outcome After Antibiotic Treatment. Reproductive Sciences, 21(5), 640-647. http://doi.org/10.1177/1933719113508817

10. Шиндлер, Адольф Е. (2011). Прогестагенные эффекты прогестерона. Здоровье женщиньl, 3(59), $138-144$.

11. В. Е. Радзинский, Ю. А. Петров, Е. А. Калинина и др (2017). Патогенетические особенности макротипов хронического эндометрита. Казанский медицинский журнал, 1(98), 27-34. 